\title{
Arsenic: metabolism and transport mechanisms in human hepatocytes
}

\author{
Hermann M. Bolt · Joanna D. Stewart
}

Published online: 15 December 2009

(C) Springer-Verlag 2009

Arsenic is a human carcinogen known to induce tumors of the urinary bladder, skin, liver and lung (Dopp et al. 2009; Beyersmann and Hartwig 2008). Genotoxicity of arsenic is not caused by direct interaction with DNA but by indirect processes, including generation of reactive oxygen species and inhibition of DNA repair processes. Drinking water represents a common source of human exposure. Tens of millions of humans in Southeast Asia routinely drink ground water with too high arsenic concentrations (Polizzotto et al. 2008). Recently, indoor combustion of high arseniccontaining coal has been reported to contribute to human exposure (Chen et al. 2007a, b, 2009; Masoudi and Saadat 2008; Lin et al. 2007).

Besides its carcinogenicity, many further toxic effects of arsenic have been reported. Examples are its compromising effect of some immune functions (Kozul et al. 2009; Conde et al. 2007), induction of alterations in DNA methylation patterns (Jensen et al. 2009), decreased glucose tolerance (Ettinger et al. 2009), inhibition of neurite growth (Frankel et al. 2009) and oxidative myocardial and liver injury (Manna et al. 2008; Gonsebatt et al. 2007).

Today, it is well accepted that the +3 methylated arsenic species are more toxic compared to the inorganic counterparts (review: Dopp et al. 2009). Methylation of inorganic arsenic mostly occurs in the liver. In this issue of the Archives of Toxicology, Miroslav Styblo from the University of North Carolina reviews metabolic pathways of arsenic in human liver particularly focusing on transporter studies performed in hepatocytes in vitro. Cultivated

H. M. Bolt · J. D. Stewart ( $\square)$

Leibniz Institut für Arbeitsforschung an der TU Dortmund, Leibniz Research Centre for Working Environment and Human Factors (IfADo), Ardeystrasse 67, 44139 Dortmund, Germany e-mail: stewart@ifado.de hepatocytes represent a well accepted in vitro system for the study of drug metabolism and toxicity (Kafert-Kasting et al. 2006; Schumann et al. 2009; Bauer et al. 2009; Godoy et al. 2009; Schug et al. 2008; Schön et al. 2008; Brulport et al. 2007; Carmo et al. 2005; Ringel et al. 2005) and have also been recommended for transporter studies (Hewitt et al. 2007). Styblo concludes that MRP2 is the most important mechanism responsible for efflux of arsenic metabolites into bile and excretion into feces. However, relatively little is known about the basolateral transport mechanisms that lead to excretion of arsenic metabolites via blood into urine.

\section{References}

Bauer A, Schumann A, Gilbert M, Wilhelm C, Hengstler JG, Schiller J, Fuchs B (2009) Evaluation of carbon tetrachloride-induced stress an rat hepatocytes by 31P NMR and MALDI-TOF mass spectrometry: lysophosphatidylcholine generation from unsaturated phosphatidylcholines. Chem Phys Lipids 159:21-29

Beyersmann D, Hartwig A (2008) Carcinogenic metal compounds: recent insight into molecular and cellular mechanisms. Arch Toxicol 82:493-512

Brulport M, Schormann W, Bauer A, Hermes M, Elsner C, Hammersen FJ, Beerheide W, Spitkovsky D, Härtig W, Nussler A, Horn LC, Edelmann J, Pelz-Ackermann O, Petersen J, Kamprad M, von Mach M, Lupp A, Zulewski H, Hengstler JG (2007) Fate of extrahepatic human stem and precursor cells after transplantation into mouse livers. Hepatology 46:861-870

Carmo H, Hengstler JG, de Boer D, Ringel M, Remiäo F, Carvalho F, Fernandes E, dos Reys LA, Oesch F, de Lourdes Bastos M (2005) Metabolic pathways of 4-bromo-2, 5 dimethoxyphenethylamine (2C-B): analysis of phase I metabolism with hepatocytes of six species including human. Toxicology 206:75-89

Chen JG, Chen YG, Zhou YS, Lin GF, Li XJ, Jia CG, Guo WC, Du H, Lu HC, Meng H, Zhang XJ, Golka K, Shen JH (2007a) A followup study of mortality among the arseniasis patients exposed to indoor combustion of high arsenic coal in Southwest Guizhou 
Autonomous Prefecture, China. Int Arch Occup Environ Health 81:9-17

Conde P, Acosta-Saavedra LC, Goytia-Acevedo RC, Calderon-Aranda ES (2007b) Sodium arsenite-induced inhibition of cell proliferation is related to inhibition of IL-2 mRNA expression in mouse activated T cells. Arch Toxicol 81:251-259

Chen JG, Lin GF, Chen YG, Jia CG, Zhou YS, Meng H, Guo WC, Golka K, Liu KJ, Shen JH (2009) Arseniasis prevalence and mortality in a multiethnic, endemic township in Guizhou, China. Int Arch Occup Environ Health 82:499-508 Epub 2008 Aug 22

Dopp E, von Recklinghausen U, Diaz-Bone R, Hirner AV, Rettenmeier AW (2009) Cellular uptake, subcellular distribution and toxicity of arsenic compounds in methylating and nonmethylating cells. Environ Res. doi:10.1016/j.envres.2009.08.012

Ettinger AS, Zota AR, Amarasiriwardena CJ, Hopkins MR, Schwartz J, Hu H, Wright RO (2009) Maternal arsenic exposure and impaired glucose tolerance during pregnancy. Environ Health Perspect 117:1059-1064 Epub 2009 Mar 11. Comment in: Environ Health Perspect 117: A310

Frankel S, Concannon J, Brusky K, Pietrowicz E, Giorgianni S, Thompson WD, Currie DA (2009) Arsenic exposure disrupts neurite growth and complexity in vitro. Neurotoxicology 30:529_ 537

Godoy P, Hengstler JG, Ilkavets L, Meyer C, Bachmann A, Müller A, Tuschl G, Mueller SO, Dooley S (2009) Extracellular matrix modulates sensitivity of hepatocytes to fibroblastoid dedifferentiation and transforming growth factor beta-induced apoptosis. Hepatology 49:2031-2043

Gonsebatt ME, Del Razo LM, Cerbon MA, Züniga O, Sanchez-Pefia LC, Ramirez P (2007) Arsenite induced oxidative damage in mouse liver is associated with increased cytokeratin 18 expression. Arch Toxicol 81:619-626

Hewitt NJ, Lechon MJ, Houston JB, Hallifax D, Brown HS, Maurel P, Kenna JG, Gustavsson L, Lohmann C, Skonberg C, Guillouzo A, Tuschl G, Li AP, LeCluyse E, Groothuis GM, Hengstler JG (2007) Primary hepatocytes: current understanding of the regulation of metabolic enzymes and transporter proteins, and pharmaceutical practice for the use of hepatocytes in metabolism, enzyme induction, transporter, clearance, and hepatotoxicity studies. Drug Metab Rev 39:159-234

Jensen TJ, Novak P, Wnek SM, Gandolfi AJ, Futscher BW (2009) Arsenicals produce stable progressive changes in DNA methylation patterns that are linked to malignant transformation of immortalized urothelial cells. Toxicol Appl Pharmacol 1(241):221-229

Kafert-Kasting S, Alexandrova K, Barthold M, Laube B, Friedrich G, Arseniev L, Hengstler JG (2006) Enzyme induction in cryopreserved human hepatocyte cultures. Toxicology 220:117-125

Kozul CD, Ely KH, Enelow RI, Hamilton JW (2009) Low-dose arsenic compromises the immune response to influenza a infection in vivo. Environ Health Perspect 117(9):1441-1447 Epub 2009 May 20. Comment in: Environ Health Perspect 2009 Sep; 117(9): A406

Lin GF, Du H, Chen JG, Lu HC, Kai JX, Zhou YS, Guo WC, Zhang XJ, Lu DR, Golka K, Shen JH (2007) Glutathione S-transferases $\mathrm{M} 1$ and T1 polymorphisms and arsenic content in hair and urine in two ethnic clans exposed to indoor combustion of high arsenic coal in Southwest Guizhou, China. Arch Toxicol 81:545-551

Manna P, Sinha M, Sil PC (2008) Arsenic-induced oxidative myocardial injury: protective role of arjunolic acid. Arch Toxicol 82:137-149

Masoudi M, Saadat M (2008) Arsenic, GSTO2 Asp142 polymorphism, health and treatment. EXCLI J 7:115-118

Polizzotto ML, Kocar BD, Benner SG, Sampson M, Fendorf S (2008) Near-surface wetland sediments as a source of arsenic release to ground water in Asia. Nature 24; 454(7203): 505-508. Comment in: Nature 24; 454(7203): 415-416

Ringel M, von Mach MA, Santos R, Feilen PJ, Brulport M, Hermes M, Bauer AW, Schormann W, Tanner B, Schön MR, Oesch F, Hengstler JG (2005) Hepatocytes cultured in alginate microspheres: an optimized technique to study enzyme induction. Toxicology 206:153-167

Schön MR, Hogrebe E, Hengstler JG, Donaubauer B, Faber SC, Bauer A, Pietsch U-C, Jelkmann W, Thiery J, Hauss JP, Tannapfel A (2008) Erythropoietin stimulates hepatocyte regeneration after liver resection. EXCLI J 7:79-92

Schug M, Heise T, Bauer A, Storm D, Blaszkewicz M, Bedawy E, Brulport M, Geppert B, Hermes M, Föllmann W, Rapp K, Maccoux L, Schormann W, Appel KE, Oberemm A, GundertRemy U, Hengstler JG (2008) Primary rat hepatocytes as in vitro system for gene expression studies: comparison of sandwich, Matrigel and 2D cultures. Arch Toxicol 82:92331

Schumann A, Bauer A, Hermes M, Gilbert M, Hengstler JG, Wilhelm C (2009) A rapid and easy to handle thermoluminescence based technique for evaluation of carbon tetrachlorideinduced oxidative stress an rat hepatocytes. Arch Toxicol 83:709-720 